Article

\title{
Flexibilisquinone, a New Anti-Inflammatory Quinone from the Cultured Soft Coral Sinularia flexibilis
}

\author{
Yu-Fang Lin ${ }^{1, \dagger}$, Chao-Ying Kuo ${ }^{2,3, \dagger}$, Zhi-Hong Wen ${ }^{1,4,5}$, Yen-You Lin ${ }^{1}$, Wei-Hsien Wang ${ }^{1,3,4}$, \\ Jui-Hsin Su ${ }^{2,3,4}$, Jyh-Horng Sheu ${ }^{1,4,5, *}$ and Ping-Jyun Sung ${ }^{1,2,3,4,6,7, *}$
}

1 Department of Marine Biotechnology and Resources, National Sun Yat-sen University, Kaohsiung 804, Taiwan; E-Mails: yvonne6819@yahoo.com.tw (Y.-F.L.); wzh@mail.nsysu.edu.tw (Z.-H.W.); chas6119@gmail.com (Y.-Y.L.); whw@nmmba.gov.tw (W.-H.W.)

2 Graduate Institute of Marine Biotechnology, National Dong Hwa University, Pingtung 944, Taiwan; E-Mails: recall04729@hotmail.com (C.-Y.K.); x2219@nmmba.gov.tw (J.-H.S.)

3 National Museum of Marine Biology and Aquarium, Pingtung 944, Taiwan

4 Division of Marine Biotechnology, Asia-Pacific Ocean Research Center, National Sun Yat-sen University, Kaohsiung 804, Taiwan

5 Doctoral Degree Program in Marine Biotechnology, National Sun Yat-sen University and Academia Sinica, Kaohsiung 804, Taiwan

6 Chinese Medicine Research and Development Center, China Medical University Hospital, Taichung 404, Taiwan

7 Graduate Institute of Natural Products, Kaohsiung Medical University, Kaohsiung 807, Taiwan

$\dagger$ These authors contributed equally to this work.

* Authors to whom correspondence should be addressed; E-Mails: sheu@mail.nsysu.edu.tw (J.-H.S.); pjsung@nmmba.gov.tw (P.-J.S.); Tel.: +886-7-525-2000 (ext. 5030) (J.-H.S.); +886-8-882-5037 (P.-J.S.); Fax: +886-7-525-5020 (J.-H.S.); +886-8-882-5087 (P.-J.S.).

Received: 27 May 2013; in revised form: 4 July 2013 / Accepted: 8 July 2013 /

Published: 10 July 2013

\begin{abstract}
A new quinone derivative, flexibilisquinone (1), was isolated from the cultured soft coral Sinularia flexibilis, originally distributed in the waters of Taiwan. The structure of quinone 1 was established by extensive spectroscopic methods, particularly 1D and 2D NMR experiments. In the in vitro anti-inflammatory effects test, quinone 1 was found to significantly inhibit the accumulation of the pro-inflammatory iNOS and COX-2 proteins of the LPS-stimulated RAW264.7 macrophage cells.
\end{abstract}


Keywords: flexibilisquinone; cultured soft coral; Sinularia flexibilis; anti-inflammatory; iNOS; COX-2

\section{Introduction}

Soft corals belonging to the genus Sinularia are well-recognized as marine organisms containing various natural products that show interesting bioactivities [1,2]. Because all the corals are claimed to be threatened species, we therefore want to culture these interesting specimens as sources of potential natural products. In previous studies on the chemical constituents of cultured octocorals, a series of interesting secondary metabolites were obtained from Erythropodium caribaeorum [3], Klyxum simplex [4-7], Lobophytum crassum [8], Sarcophyton trocheliophorum [9], Sinularia flexibilis [10], Sinularia leptoclados [11], Briareum excavatum [12-20] and Briareum sp. [21]. Two novel metabolites, pseudoalteromones A and B were obtained from a marine bacterium Pseudoalteromonas sp. CGH2XX, a bacterium originally isolated from a cultured soft coral Lobophytum crassum [22,23]. During the course of our further investigation on new natural substances from the cultured soft coral Sinularia flexibilis (Figure 1), a new quinone derivative, flexibilisquinone (1), has been isolated.

Figure 1. The cultured soft coral S. flexibilis and the structure of flexibilisquinone (1).

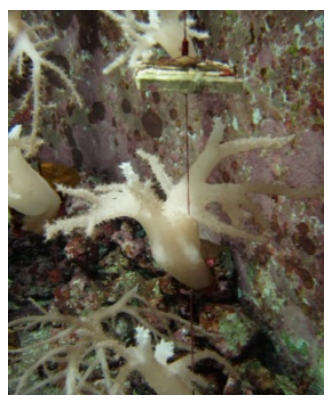

Sinularia flexibilis

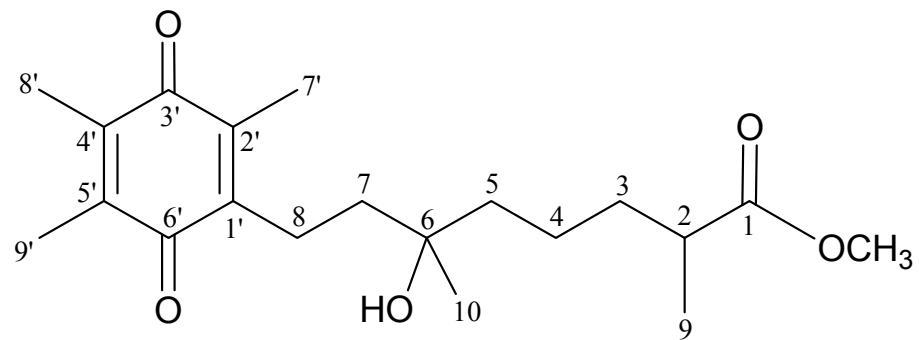

1

\section{Results and Discussion}

Flexibilisquinone (1) was isolated as a yellow oil that gave an $[\mathrm{M}+\mathrm{Na}]^{+}$ion peak at $\mathrm{m} / \mathrm{z} 373.1988$ in the HRESIMS, corresponding to a molecular formula $\mathrm{C}_{20} \mathrm{H}_{30} \mathrm{O}_{5}$ (calcd. for $\mathrm{C}_{20} \mathrm{H}_{30} \mathrm{O}_{5} \mathrm{Na}$, 373.1991) requiring six degrees of unsaturation. The IR absorptions bands at 3490, 1736, 1680 and $1642 \mathrm{~cm}^{-1}$ were characteristic of hydroxy, ester and quinone moieties, and the latter deduction was further supported by the UV absorptions at $\lambda_{\max } 262\left(\log \varepsilon\right.$ 3.8) and $267(\log \varepsilon 3.8) \mathrm{nm}$. The ${ }^{13} \mathrm{C}-\mathrm{NMR}$ data of 1 (Table 1) showed the presence of 20 carbon signals, which were identified by the assistance of a DEPT spectrum as six methyls, five $\mathrm{sp}^{3}$ methylenes, an $\mathrm{sp}^{3}$ methine, an $\mathrm{sp}^{3}$ quaternary carbon and seven $\mathrm{sp}^{2}$ quaternary carbons including three carbonyls. The ${ }^{1} \mathrm{H}-\mathrm{NMR}$ spectrum of 1 showed signals of a methoxy group $\left(\delta_{\mathrm{H}} 3.68,3 \mathrm{H}, \mathrm{s}\right)$, three vinyl methyls $\left(\delta_{\mathrm{H}} 2.03,2.01,2.01\right.$, each $\left.3 \mathrm{H} \times \mathrm{s}\right)$, a methyl doublet $\left(\delta_{\mathrm{H}} 1.17,3 \mathrm{H}, \mathrm{d}, J=7.2 \mathrm{~Hz}\right)$, a methyl singlet $\left(\delta_{\mathrm{H}} 1.22,3 \mathrm{H}\right.$, s), five pairs of aliphatic methylene protons $\left(\delta_{\mathrm{H}} 1.67,1 \mathrm{H}, \mathrm{m} ; 1.40,1 \mathrm{H}, \mathrm{m} ; 1.45,1 \mathrm{H}, \mathrm{m} ; 1.38,1 \mathrm{H}, \mathrm{m} ; 1.74-1.39,4 \mathrm{H}, \mathrm{m} ; 2.53,2 \mathrm{H}, \mathrm{m}\right)$ and an aliphatic methine proton $\left(\delta_{\mathrm{H}} 2.48,1 \mathrm{H}, \mathrm{m}\right)$. 
Table 1. ${ }^{1} \mathrm{H}-\left(400 \mathrm{MHz}, \mathrm{CDCl}_{3}\right)$ and ${ }^{13} \mathrm{C}-\left(100 \mathrm{MHz}, \mathrm{CDCl}_{3}\right) \mathrm{NMR}$ data, ${ }^{1} \mathrm{H}-{ }^{1} \mathrm{H} \mathrm{COSY}$ and HMBC correlations for quinone $\mathbf{1}$.

\begin{tabular}{|c|c|c|c|c|}
\hline Position & $\delta_{\mathrm{H}}(J$ in $\mathrm{Hz})$ & $\delta_{\mathrm{C}}$, Mult. & ${ }^{1} \mathrm{H}-{ }^{1} \mathrm{H} \mathrm{COSY}$ & HMBC $(\mathrm{H} \rightarrow \mathrm{C})$ \\
\hline 1 & & $177.2, \mathrm{C}$ & & \\
\hline 2 & $2.48 \mathrm{~m}$ & $39.4, \mathrm{CH}$ & $\mathrm{H}_{2}-3, \mathrm{H}_{3}-9$ & $\mathrm{C}-1,-3,-4,-9$ \\
\hline 3 & $1.67 \mathrm{~m} ; 1.40 \mathrm{~m}$ & $34.2, \mathrm{CH}_{2}$ & $\mathrm{H}-2, \mathrm{H}_{2}-4$ & $C-1,-2,-4,-5,-9$ \\
\hline 4 & $1.45 \mathrm{~m} ; 1.38 \mathrm{~m}$ & 21.6, $\mathrm{CH}_{2}$ & $\mathrm{H}_{2}-3, \mathrm{H}_{2}-5$ & $C-2,-3,-5,-6$ \\
\hline 5 & $1.74-1.39 \mathrm{~m}$ & $41.7, \mathrm{CH}_{2}$ & $\mathrm{H}_{2}-4$ & $C-3,-4,-6,-7,-10$ \\
\hline 6 & & $72.5, \mathrm{C}$ & & \\
\hline 7 & $1.74-1.39 \mathrm{~m}$ & $40.2, \mathrm{CH}_{2}$ & $\mathrm{H}_{2}-8$ & $C-5,-6,-8,-10,-1^{\prime}$ \\
\hline 8 & $2.53 \mathrm{~m}$ & $21.3, \mathrm{CH}_{2}$ & $\mathrm{H}_{2}-7$ & $C-6,-7,-1^{\prime},-2^{\prime},-6^{\prime}$ \\
\hline 9 & $1.17 \mathrm{~d}(7.2)$ & $17.1, \mathrm{CH}_{3}$ & $\mathrm{H}-2$ & $\mathrm{C}-1,-2,-3$ \\
\hline 10 & $1.22 \mathrm{~s}$ & $26.6, \mathrm{CH}_{3}$ & & $C-5,-6,-7$ \\
\hline $1^{\prime}$ & & 144.3, C & & \\
\hline $2^{\prime}$ & & $140.2, \mathrm{C}$ & & \\
\hline $3^{\prime}$ & & 187.6, C & & \\
\hline $4^{\prime}$ & & $140.4, \mathrm{C}^{a}$ & & \\
\hline $5^{\prime}$ & & $140.6, \mathrm{C}^{a}$ & & \\
\hline $6^{\prime}$ & & $187.2, \mathrm{C}$ & & \\
\hline $7^{\prime}$ & $2.03 \mathrm{~s}$ & $12.0, \mathrm{CH}_{3}$ & & $\mathrm{C}-1^{\prime},-2^{\prime},-3^{\prime}$ \\
\hline $8^{\prime}$ & $2.01 \mathrm{~s}$ & $12.3, \mathrm{CH}_{3}{ }^{b}$ & & $\mathrm{C}-3^{\prime},-4^{\prime},-5^{\prime}$ \\
\hline $9^{\prime}$ & $2.01 \mathrm{~s}$ & $12.4, \mathrm{CH}_{3}{ }^{b}$ & & $C-4^{\prime},-5^{\prime},-6^{\prime}$ \\
\hline $1-\mathrm{OCH}_{3}$ & $3.68 \mathrm{~s}$ & $51.5, \mathrm{CH}_{3}$ & & C-1 \\
\hline
\end{tabular}

Figure 2. The ${ }^{1} \mathrm{H}-{ }^{1} \mathrm{H}$ COSY and selective key HMBC correlations (protons $\rightarrow$ quaternary carbons) of $\mathbf{1}$.

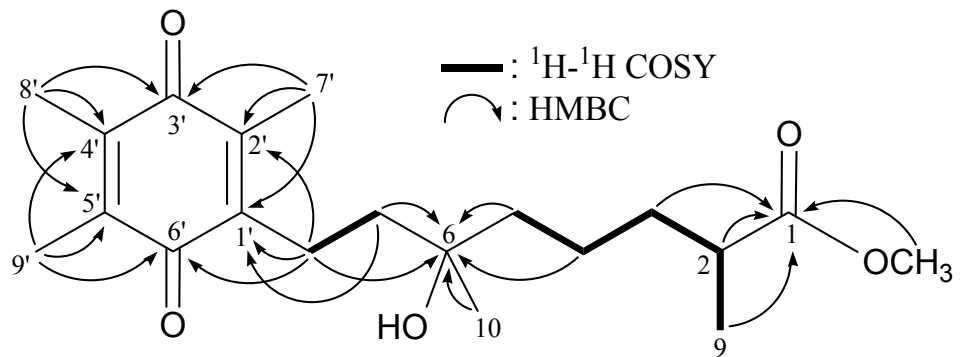

From the ${ }^{1} \mathrm{H}-{ }^{1} \mathrm{H}$ COSY spectrum of 1 (Table 1 and Figure 2), it was possible to establish the separate spin systems that map out the proton sequences from $\mathrm{H}-2 / \mathrm{H}_{2}-3 / \mathrm{H}_{2}-4 / \mathrm{H}_{2}-5, \mathrm{H}_{2}-7 / \mathrm{H}_{2}-8$ and $\mathrm{H}-2 / \mathrm{H}_{3}-9$. These data together with the key $\mathrm{HMBC}$ correlations between protons and quaternary carbons (Table 1 and Figure 2), such as $\mathrm{H}-2, \mathrm{H}_{2}-3 / \mathrm{C}-1$ and $\mathrm{H}_{2}-4, \mathrm{H}_{2}-5, \mathrm{H}_{2}-7, \mathrm{H}_{2}-8 / \mathrm{C}-6$, permitted the elucidation of the straight carbon skeleton of the side chain. The methyls at C-2 and C-6 were confirmed by the HMBC correlations between $\mathrm{H}_{3}-9 / \mathrm{C}-1,-2,-3$ and $\mathrm{H}_{3}-10 / \mathrm{C}-5,-6,-7$, respectively. The monoterpenoid side chain which is fused to the quinone moiety at $\mathrm{C}-1$ ', was elucidated by the HMBC correlations between $\mathrm{H}_{2}-7, \mathrm{H}_{2}-8 / \mathrm{C}-1^{\prime}$ and $\mathrm{H}_{2}-8 / \mathrm{C}-2^{\prime},-6$ '. The C-7', C-8' and C-9' vinyl methyls at C-2', C-4' and C-5' were established by the HMBC correlations between $\mathrm{H}_{3}-7^{\prime} / \mathrm{C}-1^{\prime},-2^{\prime},-33^{\prime} ; \mathrm{H}_{3}-8^{\prime} / \mathrm{C}-3^{\prime},-4^{\prime}$, $-5^{\prime}$; and $\mathrm{H}_{3}-9^{\prime} / \mathrm{C}-4^{\prime},-5$ ', $-6^{\prime}$, respectively. The methoxy group at $\mathrm{C}-1$ was elucidated by the HMB 
correlations between methyl group at $\delta_{\mathrm{H}} 3.68(3 \mathrm{H}, \mathrm{s})$ and an ester carbonyl at $\delta_{\mathrm{C}} 177.2(\mathrm{C})$. Based on the above findings, the structure of 1 was established unambiguously.

The spectral data of $\mathbf{1}$ were in full agreement with those of a known quinone analogue, sarcophytonone, which was isolated from a Chinese soft coral Sarcophyton crassocaule [24]. However, the optical rotation value of $1\left\{[\alpha]_{\mathrm{D}}^{23}-19.6\left(c 0.78, \mathrm{CHCl}_{3}\right)\right\}$ [25] was substantially different from that of sarcophytonone $\left([\alpha]_{\mathrm{D}}^{25}+5.82\left(c 0.40, \mathrm{CHCl}_{3}\right)\right)$, indicating that quinone 1 is an enantiomer of sarcophytonone, by comparison the structure of 1 with that of sarcophytonone.

The dose inhibition of compound 1 on LPS-induced pro-inflammatory iNOS (inducible nitric oxide synthase) and COX-2 (cyclooxygenase-2) proteins expression was evaluated by western blot analysis (Figure 3). The result clearly depicts an up-regulation of iNOS and COX-2 proteins in LPS-stimulated murine macrophage cell line. Both iNOS and COX-2 were significantly inhibited by compound $\mathbf{1}$ at 5-20 $\mu \mathrm{M}$ and $20 \mu \mathrm{M}$, respectively. Only the vehicle (DMSO) did not induce up-regulation of iNOS and COX-2 protein expression. Furthermore, compound $1(1-20 \mu \mathrm{M})$ did not induced obviously cytotoxicity in macrophage cells, as determined through Trypan blue staining.

Figure 3. Effect of compound 1 on pro-inflammatory iNOS and COX-2 protein expression in LPS-stimulated murine macrophage cell line RAW264.7. (A) Western blots for iNOS, COX-2 and $\beta$-actin proteins from macrophage cells; (B) relative density of iNOS immunoblot; (C) relative density of COX-2 immunoblot. The relative intensity of the LPS-stimulated group was taken to be $100 \%$. Band intensities were quantified by densitometry and are indicated as the percent change relative to that of the LPS-stimulated group. Compound 1 and dexamethasone (Dex) significantly inhibited LPS-induced iNOS and COX-2 protein expression in macrophage. The experiment was repeated three times. $(* p<0.05$, significantly different from the LPS-stimulated group).

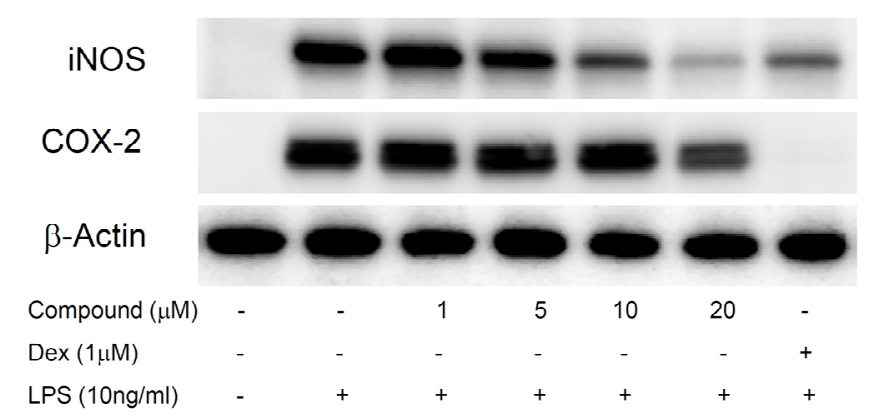

A

B

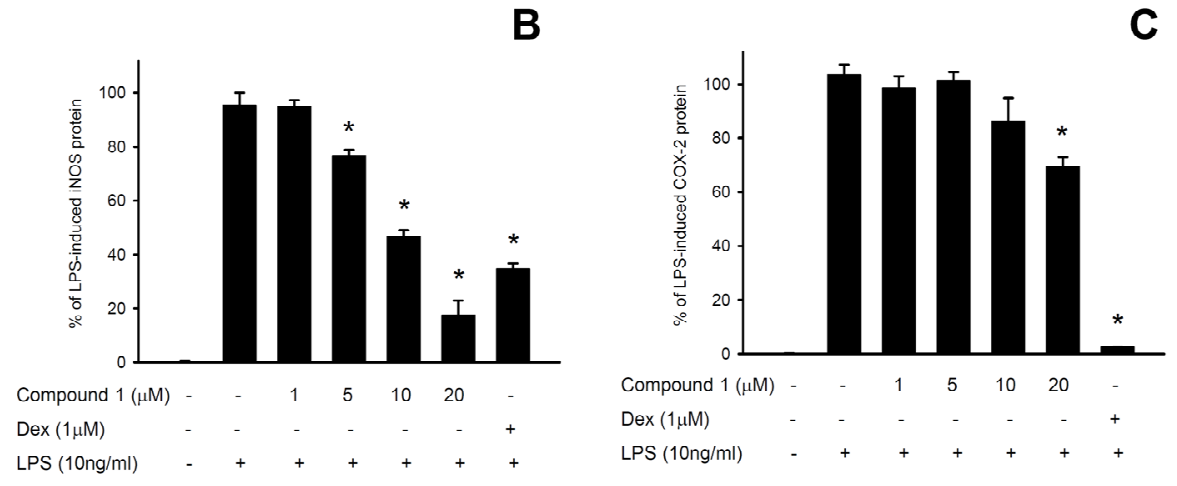




\section{Experimental}

\subsection{General}

Optical rotations were measured with a JascoP1010 digital polarimeter (Japan Spectroscopic Corporation, Tokyo, Japan). Infrared spectra were obtained on a Varian Diglab FTS 1000 FT-IR spectrophotometer (Varian Inc., Palo Alto, CA, USA). UV spectra were recorded on a Hitachi U-3210 UV spectrophotometer (Hitachi Ltd. Tokyo, Japan). NMR spectra were recorded on a Varian Mercury Plus $400 \mathrm{NMR}$ spectrometer (Varian Inc.) at $400 \mathrm{MHz}$ for ${ }^{1} \mathrm{H}$ and $100 \mathrm{MHz}$ for ${ }^{13} \mathrm{C}$ in $\mathrm{CDCl}_{3}$ at $25{ }^{\circ} \mathrm{C}$. ESIMS and HRESIMS data were recorded on Bruker APEX II mass spectrometer (Bruker, Bremen, Germany). Column chromatography was performed on silica gel (230-400 mesh, Merck, Darmstadt, Germany). TLC was carried out on precoated Kieselgel $60 \mathrm{~F}_{254}(0.25 \mathrm{~mm}$, Merck) and spots were visualized by spraying with $10 \% \mathrm{H}_{2} \mathrm{SO}_{4}$ solution followed by heating. Normal phase HPLC (NP-HPLC) was performed using a system comprised of a Hitachi L-7110 pump (Hitachi Ltd. Tokyo, Japan) and a Rheodyne 7725 injection port (Rheodyne LLC. Rohnert Park, CA, USA). A normal phase column (Supelco Ascentis ${ }^{\circledR}$ Si Cat \#:581515-U, $25 \mathrm{~cm} \times 21.2 \mathrm{~mm}, 5 \mu \mathrm{m}$, Sigma-Aldrich, St. Louis, MO, USA) was used for NP-HPLC.

\subsection{Animal Material}

Specimens of the cultured soft coral Sinularia flexibilis (specimen no. CSC-1) were collected by hand in a 80 ton cultivation tank located in the National Museum of Marine Biology and Aquarium (NMMBA), Taiwan, in July 2006 and stored in a freezer $\left(-20^{\circ} \mathrm{C}\right)$ until extraction. A voucher specimen was deposited in the Department of Marine Biotechnology and Resources, National Sun Yat-sen University, Kaohsiung, Taiwan.

\subsection{Extraction and Isolation}

The freeze-dried and minced material of the cultured soft coral Sinularia flexibilis (wet weight $1.5 \mathrm{~kg}$ ) was extracted exhaustively with ethanol $(\mathrm{EtOH})$ at $25{ }^{\circ} \mathrm{C}(1 \mathrm{~L} \times 6)$. The EtOH extract was filtered and concentrated under reduced pressure. The residue was partitioned between dichloromethane $\left(\mathrm{CH}_{2} \mathrm{Cl}_{2}\right)$ and $\mathrm{H}_{2} \mathrm{O}$. The $\mathrm{CH}_{2} \mathrm{Cl}_{2}$-soluble fraction was concentrated and the residue was chromatographed on $\mathrm{Si}$ gel by column chromatography and eluted with ethyl acetate (EtOAc) in $n$-hexane $(0-100 \%$, gradient) to yield 25 fractions. Fraction 15 , eluted with EtOAc- $n$-hexane $(1: 2)$, was further purified by NP-HPLC using EtOAc- $n$-hexane (1:5) to yield 1 (7.8 mg, $0.00052 \%)$.

Flexibilisquinone (1): $[\alpha]_{\mathrm{D}}^{23}-19.6\left(c 0.78, \mathrm{CHCl}_{3}\right)$; UV (MeOH) $\lambda_{\max }(\log \varepsilon) 262$ (3.8), 267 (3.8) nm; IR (neat) $v_{\max } 3490,1736,1680,1642 \mathrm{~cm}^{-1} ;{ }^{1} \mathrm{H}-\left(\mathrm{CDCl}_{3}, 400 \mathrm{MHz}\right)$ and ${ }^{13} \mathrm{C}-\left(\mathrm{CDCl}_{3}, 100 \mathrm{MHz}\right) \mathrm{NMR}$ data, see Table 1; ESIMS m/z 373 [M + Na] ${ }^{+}$; HRESIMS: $m / z 373.1988$ (calcd for $\mathrm{C}_{20} \mathrm{H}_{30} \mathrm{O}_{5} \mathrm{Na}, 373.1991$ ).

\subsection{In Vitro Anti-Inflammatory Assay}

Murine macrophage (RAW264.7) cell line was purchased from ATCC. In vitro anti-inflammatory activity of compound $\mathbf{1}$ was measured by examining the inhibition of lipopolysaccharide 
(LPS)-induced up-regulation of pro-inflammatory iNOS (inducible nitric oxide synthase) and COX-2 (cyclooxygenase-2) proteins expression in macrophage cells using western blotting analysis [26-28]. Briefly, inflammation in macrophages was induced by incubating them for $16 \mathrm{~h}$ in a medium containing only LPS $(10 \mathrm{ng} / \mathrm{mL})$ without compounds. For anti-inflammatory activity assay, compound 1 $(1,5,10$ or $20 \mu \mathrm{M})$ or dexamethasone (Dex; $1 \mu \mathrm{M})$ were added the cells 10 min before LPS challenge. The cells were then for western blot analysis. The immunoreactivity data are calculated with respect to the average optical density of the corresponding LPS-stimulated group. For statistical analysis, the data were analyzed by a one-way analysis of variance (ANOVA), followed by the Student-Newman-Keuls post hoc test for multiple comparisons. A significant difference was defined as a $P$ value of $<0.05$.

\section{Conclusions}

Octocorals have been well-recognized as an important source of potential medicinal-use agents. However, because of the corals are claimed to be threatened species and most of the compounds from octocorals are difficult to obtain by chemical methods, bioactive compounds from cultured soft corals will play an important role in this field. Our further studies on the chemical constituents of a cultured soft coral Sinularia flexibilis grown in the culture tanks with a flow-through sea water system located in the National Museum of Marine Biology and Aquarium, Taiwan for the extraction of additional natural products in order to establish a stable supply of bioactive material, have led to the isolation of a new quinone derivative, flexibilisquinone (1), and this compound was found to significantly inhibit the accumulation of the pro-inflammatory iNOS protein of the LPS-stimulated RAW264.7 macrophage cells, suggesting that quinone $\mathbf{1}$ is worthy of further biomedical investigation.

\section{Acknowledgments}

This work was supported by grants from the Division of Marine Biotechnology, Asia-Pacific Ocean Research Center, National Sun Yat-sen University, (Grant No. 00C-0302-05); the National Dong Hwa University; the National Museum of Marine Biology and Aquarium; and the National Science Council (Grant No. NSC 100-2320-B-110-001-MY2, 102-2325-B-291-001 and 101-2320-B-291-001-MY3), Taiwan, awarded to J.-H.S. and P.-J.S.

\section{Conflict of Interest}

The authors declare no conflict of interest.

\section{References and Notes}

1. Rocha, J.; Peixe, L.; Gomes, N.C.M.; Calado, R. Cnidarians as a source of new marine bioactive compounds-An overview of the last decade and future steps for bioprospecting. Mar. Drugs 2011, 9, 1860-1886.

2. Chen, W.-T.; Li, Y.; Guo, Y.-W. Terpenoids of Sinularia soft corals: Chemistry and bioactivity. Acta Pharm. Sinica B 2012, 2, 227-237.

3. Taglialatela-Scafati, O.; Deo-Jangra, U.; Campbell, M.; Roberge, M.; Andersen, R.J. Diterpenoids from cultured Erythropodium caribaeorum. Org. Lett. 2002, 4, 4085-4088. 
4. Chen, B.-W.; Wu, Y.-C.; Chiang, M.Y.; Su, J.-H.; Wang, W.-H.; Fan, T.-Y.; Sheu, J.-H. Eunicellin-based diterpenoids from the cultured soft coral Klyxum simplex. Tetrahedron 2009, 65, 7016-7022.

5. Chen, B.-W.; Chao, C.-H.; Su, J.-H.; Wen, Z.-H.; Sung, P.-J.; Sheu, J.-H. Anti-inflammatory eunicellin-based diterpenoids from the cultured soft coral Klyxum simplex. Org. Biomol. Chem. 2010, 8, 2363-2366.

6. Chen, B.-W.; Chao, C.-H.; Su, J.-H.; Tsai, C.-W.; Wang, W.-H.; Wen, Z.-H.; Huang, C.-Y.; Sung, P.-J.; Wu, Y.-C.; Sheu, J.-H. Klysimplexins I-T, eunicellin-based diterpenoids from the cultured soft coral Klyxum simplex. Org. Biomol. Chem. 2011, 9, 834-844.

7. Chen, B.-W.; Huang, C.-Y.; Wen, Z.-H.; Su, J.-H.; Wang, W.-H.; Sung, P.-J.; Wu, Y.-C.; Sheu, J.-H. Klysimplexins U-X, eunicellin-based diterpenoids from the cultured soft coral Klyxum simplex. Bull. Chem. Soc. Jpn. 2011, 84, 1237-1242.

8. Lee, N.-L.; Su, J.-H. Tetrahydrofuran cembranoids from the cultured soft coral Lobophytum crassum. Mar. Drugs 2011, 9, 2526-2536.

9. Su, J.-H.; Lu, Y.; Lin, W.-Y.; Wang, W.-H.; Sung, P.-J.; Sheu, J.-H. A cembranoid, trocheliophorol, from the cultured soft coral Sarcophyton trocheliophorum. Chem. Lett. 2010, 39, 172-173.

10. Su, J.-H.; Lin, Y.-F.; Lu, Y.; Yeh, H.-C.; Wang, W.-H.; Fan, T.-Y.; Sheu, J.-H. Oxygenated cembranoids from the cultured and wild-type soft corals Sinularia flexibilis. Chem. Pharm. Bull. 2009, 57, 1189-1192.

11. Tsai, T.-C.; Wu, Y.-J.; Su, J.-H.; Lin, W.-T.; Lin, Y.-S. A new spatane diterpenoid from the cultured soft coral Sinularia leptoclados. Mar. Drugs 2013, 11, 114-123.

12. Sung, P.-J.; Lin, M.-R.; Su, Y.-D.; Chiang, M.Y.; Hu, W.-P.; Su, J.-H.; Cheng, M.-C.; Hwang, T.-L.; Sheu, J.-H. New briaranes from the octocorals Briareum excavatum (Briareidae) and Junceella fragilis (Ellisellidae). Tetrahedron 2008, 64, 2596-2604.

13. Sung, P.-J.; Lin, M.-R.; Hwang, T.-L.; Fan, T.-Y.; Su, W.-C.; Ho, C.-C.; Fang, L.-S.; Wang, W.-H. Briaexcavatins $\mathrm{M}-\mathrm{P}$, four new briarane-related diterpenoids from cultured octocoral Briareum excavatum (Briareidae). Chem. Pharm. Bull. 2008, 56, 930-935.

14. Hwang, T.-L.; Lin, M.-R.; Tsai, W.-T.; Yeh, H.-C.; Hu, W.-P.; Sheu, J.-H.; Sung, P.-J. New polyoxygenated briaranes from octocorals Briareum excavatum and Ellisella robusta. Bull. Chem. Soc. Jpn. 2008, 81, 1638-1646.

15. Sung, P.-J.; Lin, M.-R.; Chiang, M.Y. The structure and absolute stereochemistry of briaexcavatin U, a new chlorinated briarane from a cultured octocoral Briareum excavatum. Chem. Lett. 2009, 38, 154-155.

16. Sung, P.-J.; Lin, M.-R.; Chiang, M.Y.; Hwang, T.-L. Briaexcavatins V-Z, discovery of new briaranes from a cultured octocoral Briareum excavatum. Bull. Chem. Soc. Jpn. 2009, 82, 987-996.

17. Sung, P.-J.; Chen, B.-Y.; Lin, M.-R.; Hwang, T.-L.; Wang, W.-H.; Sheu, J.-H.; Wu, Y.-C. Excavatoids $\mathrm{E}$ and $\mathrm{F}$ : discovery of two new briaranes from the cultured octocoral Briareum excavatum. Mar. Drugs 2009, 7, 472-482.

18. Sung, P.-J.; Chen, B.-Y.; Chiang, M.Y.; Hou, C.-H.; Su, Y.-D.; Hwang, T.-L.; Chen, Y.-H.; Chen, J.-J. Excavatoids G-K, new 8,17-epoxybriaranes from the cultured octocoral Briareum excavatum (Briareidae). Bull. Chem. Soc. Jpn. 2010, 83, 539-545. 
19. Su, J.-H.; Chen, B.-Y.; Hwang, T.-L.; Chen, Y.-H.; Huang, I.-C.; Lin, M.-R.; Chen, J.-J.; Fang, L.-S.; Wang, W.-H.; Li, J.-J.; et al. Excavatoids L-N, new 12-hydroxybriaranes from the cultured octocoral Briareum excavatum (Briareidae). Chem. Pharm. Bull. 2010, 58, 662-665.

20. Sung, P.-J.; Li, G.-Y.; Su, Y.-D.; Lin, M.-R.; Chang, Y.-C.; Kung, T.-H.; Lin, C.-S.; Chen, Y.-H.; $\mathrm{Su}$, J.-H.; Lu, M.-C.; et al. Excavatoids $\mathrm{O}$ and P, new 12-hydroxybriaranes from the octocoral Briareum excavatum. Mar. Drugs 2010, 8, 2639-2646.

21. Sung, P.-J.; Lin, M.-R.; Chiang, M.Y.; Huang, I-C.; Syu, S.-M.; Fang, L.-S.; Wang, W.-H.; Sheu, J.-H. Briarenolide D, a new hydroperoxybriarane diterpenoid from a cultured octocoral Briareum sp. Chem. Lett. 2010, 39, 1030-1032.

22. Chen, Y.-H.; Lu, M.-C.; Chang, Y.-C.; Hwang, T.-L.; Wang, W.-H.; Weng, C.-F.; Kuo, J.; Sung, P.-J. Pseudoalteromone A: A novel bioactive ubiquinone from a marine bacterium Pseudoalteromonas sp. CGH2XX (Pseudoalteromonadaceae). Tetrahedron Lett. 2012, 53, 1675-1677.

23. Chen, Y.-H.; Kuo, J.; Su, J.-H.; Hwang, T.-L.; Chen, Y.-H.; Lee, C.-H.; Weng, C.-F.; Sung, P.-J. Pseudoalteromone B: A novel 15C compound from a marine bacterium Pseudoalteromonas sp. CGH2XX. Mar. Drugs 2012, 10, 1566-1571.

24. Li, L.; Wang, C.-Y.; Shao, C.-L.; Han, L.; Sun, X.-P.; Zhao, J.; Guo, Y.-W.; Huang, H.; Guan, H.-S. Two new metabolites from the Hainan soft coral Sarcophyton crassocaule. J. Asian Nat. Prod. Res. 2009, 11, 851-855.

25. In a later study, the compound flexibilisquinone (1) was also obtained from the soft coral Lobophytum hsiehi collected off the waters of Taiwan, and the optical rotation value of this compound was recorded as $[\alpha]_{\mathrm{D}}^{25}-22.0\left(c 0.19, \mathrm{CHCl}_{3}\right)$.

26. Huang, S.-Y.; Chen, N.-F.; Chen, W.-F.; Hung, H.-C.; Lee, H.-P.; Lin, Y.-Y.; Wang, H.-M.; Sung, P.-J.; Sheu, J.-H.; Wen, Z.-H. Sinularin from indigenous soft coral attenuates nociceptive responses and spinal neuroinflammation in carrageenan-induced inflammatory rat model. Mar. Drugs 2012, 10, 1899-1919.

27. Jean, Y.-H.; Chen, W.-F.; Sung, C.-S.; Duh, C.-Y.; Huang, S.-Y.; Lin, C.-S.; Tai, M.-H.; Tzeng, S.-F.; Wen, Z.-H. Capnellene, a natural marine compound derived from soft coral, attenuates chronic constriction injury-induced neuropathic pain in rats. Br. J. Pharmacol. 2009, $158,713-725$.

28. Jean, Y.-H.; Chen, W.-F.; Duh, C.-Y.; Huang, S.-Y.; Hsu, C.-H.; Lin, C.-S.; Sung, C.-S.; Chen, I.-M.; Wen, Z.-H. Inducible nitric oxide synthase and cyclooxygenase-2 participate in anti-inflammatory and analgesic effects of the natural marine compound lemnalol from Formosan soft coral Lemnalia cervicorni. Eur. J. Pharmacol. 2008, 578, 323-331.

Sample Availability: Not available.

(C) 2013 by the authors; licensee MDPI, Basel, Switzerland. This article is an open access article distributed under the terms and conditions of the Creative Commons Attribution license (http://creativecommons.org/licenses/by/3.0/). 